\title{
Broom snakeweed control with fire on New Mexico blue grama rangeland
}

\author{
K.C. MCDANIEL, C.R. HART, AND D.B. CARROLL
}

Authors are professor and former graduate research assistants, Department of Animal and Range Sciences, New Mexico State University, Las Cruces, N.M. 88003; extension range specialist, Texas A\&M University, Texas Agricultural Extension Service, Ft. Stockton, Tex.; and 736 Crestline Lane, Mexia, Tex.

\begin{abstract}
Multiple fires conducted in spring (March-April) and summer (June-July) on blue grama (Bouteloua gracilis [H. B. K. Lag.]) grassland near Corona, N.M. were used to relate broom snakeweed (Gutierrezia sarothrae [Pursh] Britt \& Rusby) control to pre-burn vegetation, weather, and fire conditions. Spring fires moved faster and burned cooler than summer fires as indicated by measurements from thermocouples giving the fire's rate of spread, temperature, and heat. In spring, broom snakeweed was in the bud stage with little green foliage and fires provided less average crown destruction (8\%) and shrub mortality (65\%) compared to summer fires (66\% crown destruction, $92 \%$ mortality) when the shrub was growing actively. Air temperature and total fuel biomass positively influenced fire temperatures, and duration of heat above $60^{\circ} \mathrm{C}$ resulting in high broom snakeweed mortality. Conversely, as relative humidity, wind speed, and fuel moisture increased, fire heat decreased, resulting in less broom snakeweed mortality. Attempts to conduct spring or summer fires over a 6-year period in central New Mexico were complicated and often unsuccessful because of unsuitable weather and fuel conditions. We concluded ideal weather conditions must converge before, during, and after a prescribed burning event in order to maximize broom snakeweed control and forage growth on these grasslands.
\end{abstract}

Key Words: shortgrass prairie, fire temperature, fire heat, thermocouples, controlled burning, prescribed fire, weed control

Blue grama (Bouteloua gracilis [Kunth in H.B.K.] Lag. ex Griffiths) grasslands of New Mexico include varying densities of the native shrub, broom snakeweed (Gutierrezia sarothrae [Pursh] Britt. \& Rusby). This low-growing (less than $0.5 \mathrm{~m}$ tall), suffrutescent plant is considered undesirable by many landowners because it suppresses growth of associated herbage, which serve as preferred livestock and wildlife forage (Pieper and McDaniel 1989, McDaniel et al. 1993). Broom snakeweed, which is poisonous, is generally not grazed by sheep or cattle unless alternative forage is scarce (Smith and Flores-Rodriguez 1989).

Appreciation is expressed to Phil Berry and David Anderson, former graduate students, Department of Animal and Range Sciences, New Mexico State University, N.M. for their assistance in the research. We also thank Gene Parker and the Corona Ranch staff for their assistance.

Research was supported by the New Mexico Agricultural Experiment Station and funded by a State of New Mexico Legislative Appropriation and USDA-CSRS Special Grant for broom snakeweed research.

Manuscript accepted 24 Feb. 1997.
Broom snakeweed control by aerial herbicide application has been a common practice in New Mexico, especially since the registration of picloram (4-amino-3,5,6-trichloro-2-pyridinecarboxylic acid) in the early 1980s (McDaniel and Duncan 1987, McDaniel 1989). Chemical control has been concentrated on areas with high broom snakeweed numbers because the expected increase in grass production is more likely to provide a favorable economic return than treating areas with a sparse plant density (Torell et al. 1989). Prescribed burning has been used in areas where broom snakeweed is widely scattered and sufficient fine fuel exists to carry the fire (Dwyer 1969). Fine-fuel biomass on blue grama rangeland consists mainly of graminoids, which become limited under low rainfall, excessive grazing, and interference from broom snakeweed (McDaniel et al. 1993).

Experience with fire, especially under research conditions, is limited for the blue grama grasslands of New Mexico. Wright and Bailey (1982) gave a general prescription for burning low-volatile fuels typical of shortgrass prairie. They suggested burning a headfire with air temperatures from 21 to $27^{\circ} \mathrm{C}$; relative humidity, $20-40 \%$; wind speed, $3.6-6.5 \mathrm{~m} / \mathrm{sec}$; and wind direction from the southwest. Rasmussen and Wright (1988) offered a broader prescription for burning low-volatile fuel with at least $1,700 \mathrm{~kg} / \mathrm{ha}$ of broom snakeweed. They suggested air temperatures, $15-32^{\circ} \mathrm{C}$; relative humidity, $15-40 \%$; and wind speed, 2.2- $8.8 \mathrm{~m} / \mathrm{sec}$. Burning under these conditions may provide the best opportunity for a fire to move across these grasslands, but quantitative measurements describing fire temperatures and behavior are needed before effects on plants targeted for control can be explained (Rothermel and Deeming 1980, Wright and Bailey 1982).

Burning literature often describes shortgrass prairie fire temperatures as simply "cool" or "hot." These qualitative expressions are ambiguous, however, for explaining effects during and after prescribed burns (Wright and Bailey 1982). Jacoby et al. (1992) described a technique for measuring prairie fire temperatures with thermocouples and a portable, programmable high-speed high-capacity data recorder. Data acquired can be used to determine rate of fire spread, duration of heat, or residence time (Rothermel and Deeming 1980) above a given temperature, fire temperature, and degree-seconds of heat. According to Stinson and Wright (1969), heat duration above a given temperature should relate better to plant damage than total temperature, as only heat above a plant's thermal threshold may be lethal (Hare 1961). Wright and Bailey (1982) reported plant tissue death to be an exponential function between amount and duration of heat if moisture is constant. They gave $60^{\circ} \mathrm{C}$ as the thermal death point for most plants when exposed for approximately 10 minutes.

Our research investigated broom snakeweed control from fires 
burned under a range of air temperatures $\left(6-35^{\circ} \mathrm{C}\right)$ and fuel biomass conditions $(570-1,364 \mathrm{~kg} / \mathrm{ha}$ ) typically found in spring (March-April) or summer (June-July) on blue grama grasslands in central New Mexico. Our objective was to relate weather and fuel conditions with fire characteristics to develop a burning prescription for broom snakeweed control in this region.

\section{Materials and Methods}

\section{Environmental Setting}

Studies were conducted at 2 locations about $10 \mathrm{~km}$ apart on the New Mexico State University Corona Ranch, which is located 23 $\mathrm{km}$ northeast of Corona, N.M. Average annual precipitation is 397 $\mathrm{mm}$, with more than one-half the rainfall typically received during localized thunderstorms between July and September. Experiments were established on level terrain at an elevation of about $1,870 \mathrm{~m}$. The soils at both sites are comprised of the TaipaDean loam association, which are shallow and underlain by a highly calcareous limestone bedrock. The Taipa loam is a fineloamy, mixed, mesic, Ustollic Haplargid, and the Dean loam is a fine carbonatic, mesic Ustollic Calcioathid. Broom snakeweed was the dominant overstory plant and ranged from 15 to $45 \mathrm{~cm}$ in height, with an average density of 3 plants $/ \mathrm{m}^{2}$. Other common plants beside blue grama and broom snakeweed included winterfat (Ceratoides lanata [Pursh] J.T. Howell), cholla (Opuntia imbricata [Haw.] DC), wolftail (Lycurus phleoides [H.B.K.], sand dropseed (Sporobolus cryptandrus [Torr.] A. Gray), squirreltail (Elymus longifolius [Smith] Gould), and threeawns (Aristida spp.). Broadleaf herbs were relatively uncommon, with scarlet globemallow (Sphaeralcea coccinea [Nutt.] Rydb.), and verbena (Verbena bracteata Lag. \& Rodr.) most abundant.

Burns were conducted from 1990 through 1993 as headfires to 20-by-26.5-m plots placed within 8-ha fenced exclosures at each site. A 6.7-m buffer was installed around each plot using a grader to remove vegetation and create a mineral fire break. We burned plots in either early spring (between 20 March and 6 April) or early summer (between 25 June and 8 July). We had intended to burn in fall (October), but there was always a high proportion of green-to-dead blue grama leaf material during this time, and fires would not carry. Blue grama was the primary fine fuel and was largely quiescent with little green growth during both burning periods in 1990 and 1991. In spring 1992, as well as summer 1992 and 1993, blue grama was actively growing and high plant moisture (above $25 \%$ ) prevented us from burning. We planned to burn in 1994 and 1995, but attempts in both spring and summer were unsuccessful, again because of high blue grama moisture and unsuitable weather conditions. Blue grama in the study area usually remains winter quiescent until soil moisture is sufficient and minimum soil temperatures exceed about $10^{\circ} \mathrm{C}$ at a $10-\mathrm{cm}$ depth. Under these conditions, blue grama generally initiates leaf and tiller growth in mid-April and will remain green throughout the growing season unless soil water becomes limiting, at which time the plant becomes summer quiescent. This usually occurs when rainfall is below the $60-\mathrm{mm}$ average normally received in May and June; thus a burning window is created until expected rainfall is received in July. When we burned in spring, broom snakeweed contained mostly woody and flower material produced the previous year, with little green tissue except for primordial buds located on lower stems. During summer burns, shoots and leaves were fully elongated, as the majority of the annual vegetative growth broom snakeweed produces was complete.

In preparation for burning each plot, ten 31.5-by-61-cm quadrats were permanently marked with metal stakes and placed along each of 2 transects located diagonally across each plot. Bare ground, litter, grass, forb, and broom snakeweed cover was estimated in the permanent quadrats as a proportion of $100 \%$ surface cover. Fine fuel and broom snakeweed biomass was determined using double sampling procedures (Bonham 1989) by placing the 31.5 -by- $61-\mathrm{cm}$ sample frame adjacent to the permanently marked quadrats. Two of 10 sample frames were clipped $0.5 \mathrm{~cm}$ above the surface. This material was weighed in the field, oven-dried, and reweighed to determine fine-fuel and broom snakeweed moisture. Estimated weights were corrected to a dryweight basis using the clipped material and regression techniques (Bonham 1989). Gravimetric soil moisture to a 10-cm depth was determined before burning by placing 6 random soil core samples per plot in separate air-tight containers and weighing them fresh and after oven-drying. Air temperature, soil temperature at 10 and $50 \mathrm{~cm}$, relative humidity, wind speed, and direction were recorded throughout the study by permanently installed CR-10 multiport data loggers ${ }^{1}$ placed near the center of each exclosure.

In 1990 we conducted 6 spring ( 3 at each site) and 6 summer fires and obtained weather and pre-burn vegetation data, but we did not have an operational thermocouple system to record certain fire measurements (average maximum thermocouple temperature, rate of spread, duration of heat, degree-seconds, and frontal fire intensity). In 1991, the thermocouple system was operational and we conducted 25 spring fires and 14 summer fires. In 1993, 6 spring fires were completed and fire measurements were recorded. Fire temperatures were obtained by placing temperature-sensitive tablets ${ }^{2}$ and thermocouples at the corners of a 13-by-17-m rectangle centered around a fifth location near the middle of each plot. The tablets, with melting points ranging from $66^{\circ}$ to $204^{\circ} \mathrm{C}$ at $27.6^{\circ} \mathrm{C}$ intervals, were attached to heat-retardant (asbestos) cloth and placed on the soil surface beneath the thermocouples. The thermocouples were fused to 30 -m lengths of 24 awg glassinsulated type $\mathrm{K}$ (Chromel-Alumel) wire over-braided with stainless steel $^{3}$ and were attached to small metal stakes $10-\mathrm{cm}$ above the soil surface to coincide with the average maximum fuel bed height as recommended by Jacoby et al. (1992). Thermocouple readings were received at half-second intervals by a portable multiport data logger and transferred directly to a storage module ${ }^{4}$ arrayed to record the year, Julian day, hour, minute, second, reference ambient temperature, and fire temperature for each thermocouple. Details for programing our CR-10 unit and terminology used for describing fire measurements are similar to those given by Jacoby et al. (1992). The maximum fire temperature was calculated as an average of peak temperatures recorded across the 5 thermocouple locations. The computer recorded the time a specific thermocouple was reached by the fire front and the time it took to reach a downwind thermocouple, indicating rate of fire spread. Duration of heat was calculated as the average

\footnotetext{
Campbell Scientific model CR-10 data logger powered by a solar recharged battery system.

${ }^{2}$ Tempilstik, Tempil Div., Big Three Industries, Inc., Hamilton Blvd., South Plainfield, N.J. 07090.

${ }^{3}$ Thermocouple wire and junctions were made by Omega Technologies Co., Box 4047, Stamford, Conn. 06907.

${ }^{4}$ Campbell Scientific model CR-10 data logger and SM 192 storage module.
} 
time in seconds the 5 thermocouples remained above $60^{\circ} \mathrm{C}$. Amount of heat, expressed as degree-seconds, was derived from time-temperature curves prepared for each thermocouple, and computed by summing temperatures above $60^{\circ} \mathrm{C}$ and dividing by 2 , because measurements were made at half-second intervals. We then calculated Bryam's (1959) frontal fire intensity equation using procedures described by Alexander (1982). Numerically, frontal fire intensity $(\mathrm{kW} / \mathrm{m})$ is the product of available fuel $\left(\mathrm{kg} / \mathrm{m}^{2}\right)$, heat yield of the fuel $(\mathrm{Kj} / \mathrm{kg})$, and the forward rate of spread of the fire front $(\mathrm{m} / \mathrm{s})$ (Roberts et al. 1988). We did not measure the heat yield of fine-fuel from our study area, but assumed the net heat of combustion for blue grama fuel to be $16,000 \mathrm{Kj} / \mathrm{kg}$ as suggested by Clark (1983). A reduction correction was made on this heat yield estimate using fine-fuel moisture obtained for each fire (Alexander 1982). Fire events were also hand-timed from initiation to last flame across the entire plot and expressed as total burn time.

Before burning each plot, broom snakeweed plants were counted in the permanent quadrats to determine density. A thin, colored (telephone) wire was secured to the base of each plant for future identification, and the number of basal stems, height, and canopy diameter were recorded on each marked plant. One month after each burn the marked plants were revisited and the crown was noted as completely burned to the ground or not burned to the ground (stems charred but standing). Plants were also classified as having no growth, aerial growth (green growth apparent on standing stems), or basal growth (meaning top was killed but green growth was evident near the base). A final determination of broom snakeweed mortality was made near the end of the first growing season (October) by averaging estimates made by 3 observers who evaluated plant control in burned plots compared to nonburned plots.

Explanatory variables used to relate weather and pre-burn vegetation conditions to fire measurements during the spring and summer burning seasons are defined in Table 1 . The dependent fire-related variables included maximum average fire temperature recorded by the thermocouples and temperature-sensitive tablets, rate of spread, total burn time, duration of heat, and degree-seconds of heat. Additional regressions were conducted with broom snakeweed mortality as the dependent variable, and to avoid multi-collinearity, with selected fire, weather, and pre-burn vegetation measurements as independent variables. Linear and nonlinear regression routines and stepwise discriminate analyses (SAS 1984) as suggested by Britton and Wright (1971) were used to compare the relative importance of the independent variables in accounting for the variation in broom snakeweed mortality.

\section{Results and Discussion}

\section{Pre-burn Conditions}

The range of weather variables under which plots were burned in spring were air temperature, $4.4-24.8^{\circ} \mathrm{C}$; wind $3-10 \mathrm{~m} / \mathrm{s}$; and relative humidity $13-45 \%$ (Table 2 ). Fine-fuel biomass (mostly grass) varied from 176 to $850 \mathrm{~kg} / \mathrm{ha}$ and broom snakeweed biomass varied from 16 to $2,510 \mathrm{~kg} / \mathrm{ha}$. Spring fine-fuel moisture ranged from 4 to $16 \%$; soil moisture from 2 to $11 \%$; and soil temperature at $10-\mathrm{cm}$ depth, from 4 to $20^{\circ} \mathrm{C}$. In summer, air temperature ranged from 20.6 to $35.3^{\circ} \mathrm{C}$; wind $3-8 \mathrm{~m} / \mathrm{s}$; and relative humidity $9-39 \%$. Fine-fuel biomass varied from 290 to 786 $\mathrm{kg} / \mathrm{ha}$; broom snakeweed biomass ranged from 59 to $1,500 \mathrm{~kg} / \mathrm{ha}$.
Table 1. Variables used in defining vegetation, weather, and fire values.

\begin{tabular}{ll}
\hline \hline Variables & Variable description \\
\hline FFCOV & Fine-fuel cover (\%) \\
SCCOV & Broom snakeweed fuel cover (\%) \\
LTCOV & Litter cover (\%) \\
BGCOV & Bare ground cover (\%) \\
FFBIO & Fine-fuel biomass $(\mathrm{kg} / \mathrm{ha})$ \\
SCBIO & Broom snakeweed biomass (kg/ha) \\
TOTBIO & Total fuel biomass (kg/ha) \\
GUDEN & Broom snakeweed density (no/m2) \\
FFMOS & Fine-fuel moisture (\%) \\
SCMOS & Broom snakeweed fuel moisture (\%) \\
TOTMOS & Total fuel moisture (\%) \\
ATEMP & Air temperature (C) \\
STEMP & Soil temperature $10-\mathrm{cm}$ depth (C) \\
RH & Relative humidity (\%) \\
WS & Wind speed (m/s) \\
WD & Wind direction \\
SMOS & Soil moisture (\%) \\
TCT & Average maximum thermocouple temperature at 10-cm \\
& above soil surface (C) \\
TST & Average maximum tablet temperature on soil surface (C) \\
TBT & Total burn time (min) \\
ROS & Rate of fire spread (m/s) \\
DOH & Duration of heat above $60 \mathrm{~s}$ \\
DSH & Degree seconds of heat \\
FFI & Frontal fire intensity (kW/m) \\
\hline
\end{tabular}

Summer fine-fuel moisture ranged from 9 to $12 \%$; soil moisture, $2-13 \%$; and soil temperature at $10-\mathrm{cm}, 21-33^{\circ} \mathrm{C}$.

\section{Burning Conditions}

Blue grama grasslands in central New Mexico are inherently difficult to burn under prescribed conditions because of unpredictable climatic conditions and a generally inadequate fuel source (Wright and Bailey 1982). Dried fine fuels necessary to carry the fire are often lacking in amount and continuity, and when grasses are succulent they will not burn except under extreme circumstances. For example, after repeated ignition efforts we found fires failed to move across plots even under high temperatures and windy conditions when the primary fine-fuel source, blue grama, was green and its moisture content exceeded about $25 \%$. The presence of broom snakeweed can further exacerbate problems with burning, because as canopy cover increases, grass growth diminishes dramatically beneath and near the shrub (McDaniel et al. 1993); thus areas with excessive amounts of broom snakeweed (>500 kg/ha) and low fine-fuel biomass $(<350 \mathrm{~kg} / \mathrm{ha}$ ) are often precluded from prescribed burning and are probably better suited for other means of control, such as herbicide spraying (McDaniel and Duncan 1987).

On our study areas, pre-burn vegetation conditions including biomass, cover, and broom snakeweed density were similar when averaged across sites (data not shown), but conditions varied among specific plots and burning periods (Table 2). Fine-fuel moisture was usually lower in spring than in summer, but this material was easily burned when moisture was less than $15 \%$. As expected, air and soil temperatures were higher in summer than spring. Wind speed was variable, but averaged about $5 \mathrm{~m} / \mathrm{sec}$ and prevailed mostly from the west in spring, and more from the south in summer. Fire temperatures as measured by the temperature-sensitive tablets ranged from 56 to $154^{\circ} \mathrm{C}$ (average $=103^{\circ} \mathrm{C}$ ) in spring, and from 37 to $204^{\circ} \mathrm{C}$ (average $=131^{\circ} \mathrm{C}$ ) in summer 
Table 2. Range of weather and fuel conditions associated with burning periods on blue grama grasslands on the New Mexico State University Corona Research Ranch.

\begin{tabular}{|c|c|c|c|c|c|}
\hline & \multicolumn{2}{|c|}{1990} & \multicolumn{2}{|c|}{1991} & \multirow{2}{*}{$\frac{1993}{\text { Spring }}$} \\
\hline & Spring & Summer & Spring & Summer & \\
\hline Air temperature $\left({ }^{\circ} \mathrm{C}\right)$ & $4-24$ & $23-26$ & $6-25$ & $21-35$ & $18-25$ \\
\hline Soil temperature@10-cm $\left({ }^{\circ} \mathrm{C}\right)$ & $4-23$ & $21-26$ & $6-18$ & $24-33$ & $11-20$ \\
\hline Soil moisture (\%) & $7-11$ & $11-13$ & $2-11$ & $2-13$ & $4-10$ \\
\hline Relative humidity (\%) & $19-26$ & $14-26$ & $13-45$ & $9-39$ & $12-14$ \\
\hline Wind speed $(\mathrm{m} / \mathrm{s})$ & $3-5$ & $5-7$ & $3-10$ & 3-8 & $3-6$ \\
\hline Fine-fuel biomass (kg/ha) & $176-392$ & $290-633$ & $386-850$ & $338-786$ & $500-783$ \\
\hline Broom snakeweed biomass (kg/ha) & 484-985 & $763-1500$ & 16-977 & $59-1110$ & $276-2,510$ \\
\hline Fine-fuel moisture (\%) & $5-16$ & $9-12$ & $7-8$ & $10-12$ & 4-10 \\
\hline Broom snakeweed moisture (\%) & $15-29$ & $7-30$ & $27-32$ & $25-26$ & $16-27$ \\
\hline Fine-fuel cover $(\%)$ & $51-66$ & $35-64$ & $43-84$ & $44-88$ & $16-21$ \\
\hline Broom snakeweed cover $(\%)$ & $11-19$ & $12-24$ & $3-30$ & 2-37 & $7-22$ \\
\hline Bare ground (\%) & $17-30$ & $15-38$ & $9-36$ & $9-35$ & $10-45$ \\
\hline Litter $(\%)$ & 1-13 & $1-6$ & $1-8$ & $1-13$ & $1-7$ \\
\hline Broom snakeweed density $\left(\mathrm{no} / \mathrm{m}^{2}\right)$ & $4-11$ & $3-7$ & $1-11$ & $1-13$ & $2-5$ \\
\hline Number of completed burns & 6 & 6 & 25 & 14 & 6 \\
\hline
\end{tabular}

(data not shown). These temperatures are comparable to those obtained burning buffalograss (Buchloe dactyloides [Nutt.] Engelm.) prairie in Texas where soil surface temperatures averaged $104^{\circ} \mathrm{C}$ (Heirman and Wright 1973). Fire temperature measurements made with thermocouples placed $10-\mathrm{cm}$ above the soil surface recorded hotter temperatures from being exposed to direct flame than the heat-sensitive tablets on the soil surface (Table 3). This agrees with Engel et al. (1989), who reported higher thermocouple temperatures above the soil surface $(15-\mathrm{cm})$ than at the surface level. Tablet and thermocouple temperatures were correlated $(r=.75)$, but thermocouple temperatures averaged about $60 \%$ higher than tablets. Stinson and Wright (1969) reported tablets averaged $10 \%$ lower temperatures than thermocouple estimates when both were placed together on the soil surface. It should be noted there are discrepancies when recording fire temperatures from the tablets, because determining the melting point is difficult and can only be read at $27.6^{\circ} \mathrm{C}$ intervals.

Most of the burns were conducted in 1991 ( 39 of 57). During these burns spring fires usually moved faster across plots and generated less heat relative to summer burns, as indicated by the rate of fire spread and thermocouple temperatures (Table 3). On average, rate of fire spread was twice as fast in spring compared

Table 3. Fire measurements associated with 1991 burning periods on blue grama grasslands on the New Mexico State University Corona Research Ranch.

\begin{tabular}{|c|c|c|}
\hline & 19 & \\
\hline & Spring $^{1}$ & Summer ${ }^{2}$ \\
\hline $\begin{array}{l}\text { Average maximum temperature }\left({ }^{\circ} \mathrm{C}\right) \\
\text { Thermocouple at } 10-\mathrm{cm} \text { height } \\
\text { Tablet at } 0-\mathrm{cm} \text { height }\end{array}$ & $\begin{array}{l}250(12)^{3} \\
101(6)\end{array}$ & $\begin{array}{l}291(32) \\
132(12)\end{array}$ \\
\hline $\begin{array}{l}\text { Fire movement } \\
\text { Total burn time }(\mathrm{min})^{4} \\
\text { Rate of spread }(\mathrm{m} / \mathrm{s}) \\
\text { Frontal fire intensity }(\mathrm{kW} / \mathrm{m})\end{array}$ & $\begin{array}{l}1.9(0.2) \\
0.6(0.1) \\
4503(394)\end{array}$ & $\begin{array}{l}5.8(1.2) \\
0.3(0.1) \\
2535(778)\end{array}$ \\
\hline $\begin{array}{l}\text { Fire heat } \\
\text { Duration of heat (s) } \\
\text { Degree seconds of heat }\left({ }^{\circ} \mathrm{C} \times \mathrm{s}\right)\end{array}$ & $\begin{array}{l}37(3) \\
10,701(893)\end{array}$ & $\begin{array}{l}49(5) \\
16,014(2,141)\end{array}$ \\
\hline
\end{tabular}

to summer and largely influenced the calculation of frontal fire intensity, which was $44 \%$ higher in spring than summer. Duration of heat above $60^{\circ} \mathrm{C}$ averaged $37 \mathrm{sec}$ in spring and $49 \mathrm{sec}$ in summer, which is less than the average $63 \mathrm{sec}$ reported when burning tallgrass prairie in Oklahoma (Engle et al. 1989). As indicated by degree-seconds of heat, summer fires generated more heat than spring fires.

\section{Influence of Spring Burning on Broom Snakeweed}

Fuel material on broom snakeweed in early spring consists of numerous dried flowers and their supporting branches grown the previous year from the plant's perennial semi-woody base. This standing material lacks leaves, except for primordial buds, and is highly combustible and readily consumed by fire, provided there is sufficient understory fine fuel to move the fire from plant to plant. During spring, the fire front moved rapidly through the crown, removing smaller desiccated material, but larger supporting branches were often only charred and most shrubs (92\%) were not burned completely to the ground (Table 4). This presents a problem, because if the plant is not exposed to enough heat to consume the entire crown, broom snakeweed may survive by producing shoots from undamaged primordial buds located on lower stems. Of plants that survived spring burning (averaged over years and sites), most (94\%) produced shoots from the basal area at or near the surface rather than from the outer reaches of

Table 4. Average broom snakeweed crown destruction and survival after spring and summer fires in 1990, 1991, and 1993 on blue grama grasslands on the New Mexico State University Corona Research Ranch.

\begin{tabular}{lcc}
\hline \hline & \multicolumn{2}{c}{ Burming period } \\
\cline { 2 - 3 } & Spring & Summer \\
\hline Crown destruction & \multicolumn{2}{c}{ (\% of tutal plants) -..--.- } \\
$\quad$ Burned to ground & 92 & 66 \\
$\quad$ Not burned to ground & & 34 \\
Plant survival & 2 & \\
$\quad$ Aerial regrowth & 33 & 7 \\
Basal regrowth & 65 & 92 \\
No regrowth & & \\
\hline
\end{tabular}


standing stems. Neither broom snakeweed survival nor crown destruction was found to be related to shrub size, vigor, or proximity of a broom snakeweed plant to another shrub (data not shown, Hart 1992).

Fires moved easily across the landscape when fine-fuel moisture was below $15 \%$ (rate of spread averaged $0.6 \mathrm{~m} / \mathrm{s}$ ) and usually required only 2 to $3 \mathrm{~min}$ to burn entirely across a plot. Total burn time decreased proportionally with higher air temperatures $(r=-$ $0.32, P=0.10)$ and fine-fuel biomass $(r=0.37, P=0.10)$, but fires were slowed with increased bare ground $(r=0.35, P=0.05)$ (Table 5). The rate of spread model indicated the importance of wind speed, which agrees with several researchers who have reported a positive influence of wind on flame movement (Britton and Wright 1971, Hare 1961, Heyward 1938). For safety reasons, we restricted fires to wind speeds below $10 \mathrm{~m} / \mathrm{s}$. Fire movement was reduced in certain plots having exceptionally high broom snakeweed numbers, but overall broom snakeweed biomass was significantly $(P=0.001)$ and positively correlated to maximum average thermocouple temperatures $(r=0.62)$, duration of heat $(r=0.49)$, and degree-seconds of heat $(r=0.76)$.
Broom snakeweed mortality after burning 39 plots in spring averaged $65 \%$ across years and sites, and ranged from 28 to $97 \%$ (Table 4). Wind speed was the only independent weather variable to account for a significant $(r=-0.37, P=0.05)$ amount of variation in broom snakeweed mortality. Under higher wind speeds (about $>8 \mathrm{~m} / \mathrm{s}$ ), we observed the fire front to move rapidly through the shrub's crown resulting in less burn-down, and subsequently fewer plants killed. Britton and Wright (1971) reported a proportional increase in mesquite stem ignition when wind speed and fine-fuel amounts increased. However, we speculate that high winds in spring negatively influence broom snakeweed control, because heat delivered to primordial buds on lower stems is insufficient to kill this tissue. This agrees, in part, with the spring predictive equations derived from fire measurements (Table 6), which suggest relatively slow, hot fires that create a longer duration of heat resulted in greater broom snakeweed mortality. Spring fires with average maximum thermocouple temperatures below $300^{\circ} \mathrm{C}$ reduced snakeweed by $50 \%$, whereas temperatures above $350^{\circ} \mathrm{C}$ reduced broom snakeweed more than $80 \%$. Fires with a duration of heat above $60^{\circ} \mathrm{C}$ longer than $45 \mathrm{sec}$ (the

Table 5. Estimated equations defining fire measurements to preburn vegetation and weather conditions during spring and summer burning periods on the New Mexico State University Corona Research Ranch. Variables are defined in Table 1.

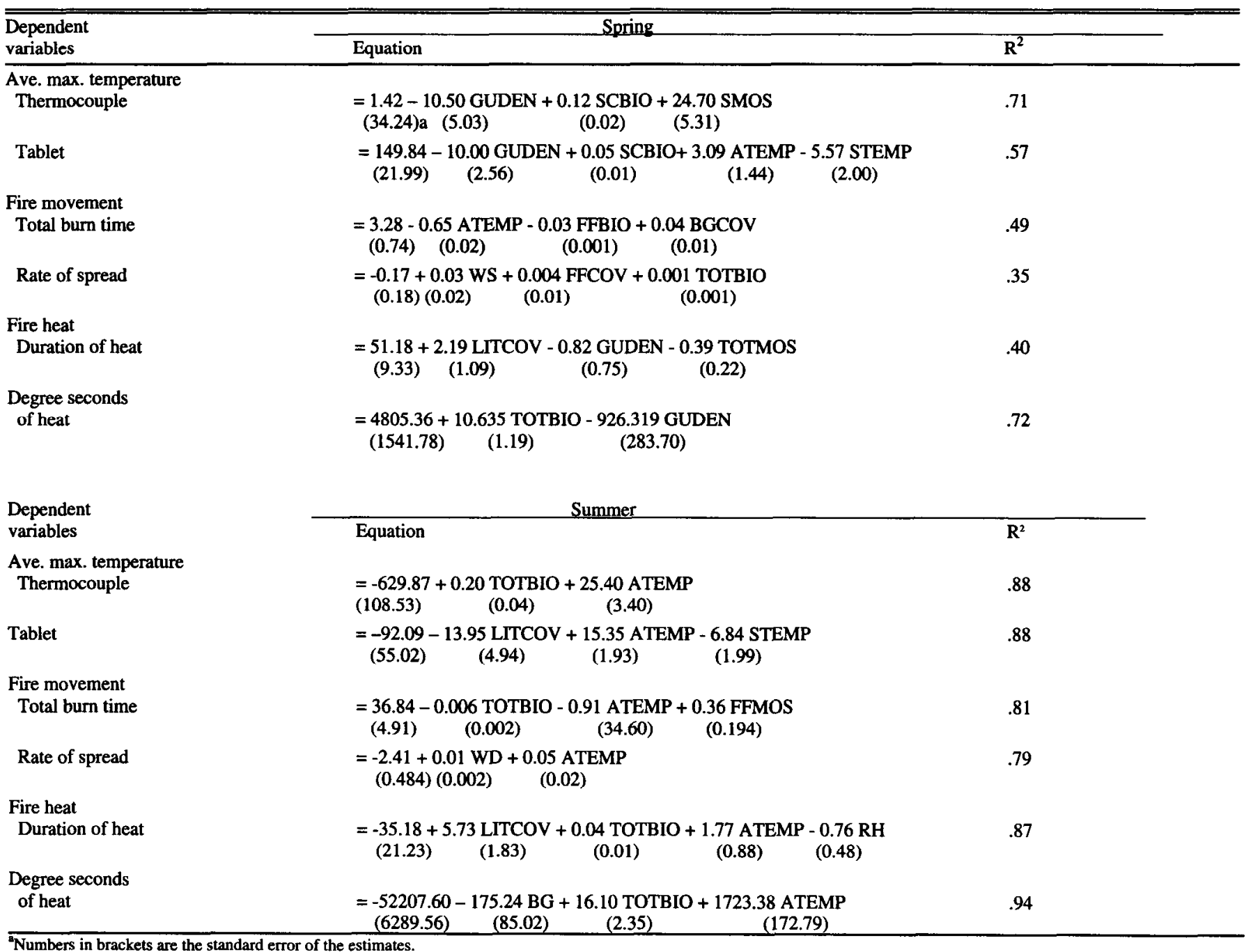

${ }^{\mathrm{a}}$ Numbers in brackets are the standard error of the estimates. 
Table 6. Estimated equations defining broom snakeweed mortality to preburn vegetation, and weather, fire, and combined conditions during spring and summer burning periods on the New Mexico State University Corona Research Ranch. Variables are defined in Table 1.

\begin{tabular}{|c|c|c|}
\hline \multirow{2}{*}{$\begin{array}{l}\text { Data } \\
\text { source }\end{array}$} & \multicolumn{2}{|l|}{ Spring } \\
\hline & Equation & $\mathbf{R}^{2}$ \\
\hline $\begin{array}{l}\text { Pre-burn } \\
\text { vegetation } \\
\text { and weather }\end{array}$ & $\begin{aligned}= & 102.01-4.01 \mathrm{WS}+1.73 \text { ATEMP }-0.35 \mathrm{BG}-1.06 \text { TOTMOS } \\
& (15.15)(1.41) \\
(0.31) & (0.13)\end{aligned}$ & .47 \\
\hline Fire & $\begin{aligned}= & 21.33-8.84 \mathrm{TBT}+0.27 \mathrm{TCT}+1.99 \mathrm{DOH}-0.007 \mathrm{DSH} \\
& (19.6)(3.59) \quad(0.69) \\
(0.53) & (0.001)\end{aligned}$ & .33 \\
\hline Combined & $\begin{array}{l}=9.20+0.34 \text { TOTCOV }-3.96 \mathrm{WS}+1.69 \text { ATEMP }+0.44 \mathrm{DOH} \\
(15.25)(0.12)\end{array}$ & .55 \\
\hline Data & Summer & \\
\hline $\begin{array}{l}\text { source } \\
\text { Pre-burn } \\
\text { vegetation } \\
\text { and weather }\end{array}$ & $\begin{array}{c}=193.33-1.70 \text { TOTMOS }-2.89 \text { WS }-1.85 \mathrm{RH} \\
(20.50) \\
(0.47)\end{array}$ & .80 \\
\hline Fire & $\begin{array}{l}=43.12+0.33 \mathrm{TST}+0.54 \mathrm{DOH}-0.002 \mathrm{DSH} \\
(7.18)(0.09) \quad(0.27) \quad(0.001)\end{array}$ & .84 \\
\hline Combined & $\begin{array}{c}=84.84+0.21 \text { FFCOV }-4.05 \text { WS }-1.13 \mathrm{RH}+0.54 \mathrm{DOH} \\
\begin{array}{ccccc}(23.57) & (0.19) & (1.43) & (0.40) & (0.17)\end{array}\end{array}$ & .90 \\
\hline
\end{tabular}

upper end of durations obtained) reduced broom snakeweed by at least $70 \%$; those with durations shorter than 45 sec gave highly variable results. Frontal fire intensities varied from 1,078 to $13,093 \mathrm{Kw} / \mathrm{m}$, but no significant correlation was found between this computation and broom snakeweed mortality.

\section{Influence of Summer Burning on Broom Snakeweed}

Low fuel moisture conditions are a prerequisite for fire to move across blue grama grassland. This situation in summer, however, results from low soil moisture and grasses that are stressed. During summer quiescence, blue grama consists mainly of dead dried leaf and stem material, but the crown usually remains green near the soil surface. In contrast, broom snakeweed usually remains green and turgid unless soil water is exceptionally limiting, in which case the shrub will shed leaf and small stem material (DePuit and Caldwell 1975). Under normal growing conditions in central New Mexico, most annual leaf and stem growth on broom snakeweed is complete by early June, and the shrub is easily ignited. We observed that most plants $(66 \%)$ immersed in flame burned completely to the ground and later died $(92 \%$ average mortality, Table 4). Surviving shrubs usually did not ignite totally and escaped complete crown burn-down.

During summer burns thermocouple fire temperatures were particularly sensitive to the amount of total fuel available and air temperatures (Table 5). For example, on plots burned below $30^{\circ} \mathrm{C}$ having a total fuel biomass below $750 \mathrm{~kg} / \mathrm{ha}$, average maximum fire temperatures recorded by the thermocouples ranged from $106^{\circ}$ to $217^{\circ} \mathrm{C}\left(\overline{\mathrm{x}}=145^{\circ} \mathrm{C}\right)$. By comparison, fire temperatures on plots burned above $30^{\circ} \mathrm{C}$ with more than $750 \mathrm{~kg} / \mathrm{ha}$ total fuel biomass ranged from 385 to $519^{\circ} \mathrm{C}\left(\bar{x}=435^{\circ} \mathrm{C}\right)$. Regression models combining only air temperature and total fuel biomass accounted for more than $80 \%$ of the variation in thermocouple temperature, total burn time, duration of heat, and degree-seconds of heat. Bare ground negatively influenced heat produced when burning, and when combined with air temperature and total fuel biomass in a regression model, they collectively accounted for $94 \%$ of the variation in degree-seconds of heat (Table 5).

On average, summer fires that generated average maximum soil surface (tablet) temperatures above $125^{\circ} \mathrm{C}$ and durations of heat above $60^{\circ} \mathrm{C}$ for longer than $45 \mathrm{sec}$ reduced broom snakeweed 96\% (Fig. 1). Combining these 2 fire measurements with degreeseconds of heat in a regression equation accounted for $84 \%$ of the variation for explaining broom snakeweed mortality (Table 6). As expected, relative humidity $(r=-0.83, P<.01)$, wind speed $(r=-$ $0.21, P .05)$, and total fuel moisture $(r=-0.16, P<.10)$ negatively influenced broom snakeweed mortality during summer burning because they are negatively related to fire intensity (Scifres 1980). Conversely, the positive influence of fine-fuel cover $(r=0.25, P<0.5)$ and air temperature $(r=.72, P<0.01)$ produced fires with a longer duration of heat $(r=0.75, P<0.01)$ and greater broom snakeweed control. No significant correlations were found between broom snakeweed mortality and variables related to fire movement, including rate of spread, total burn time, and frontal fire intensity. We noted a trade off, however, with fires that killed all broom snakeweed but were probably too hot and resulted in grass damage the first and second growing season after burning (Hart 1992). A simple linear regression between average maximum thermocouple temperatures and postburn grass biomass showed a negative relationship $(\mathrm{r}=-0.43, \mathrm{P}<$ 0.01 ) as fire temperatures recorded by the thermocouples above $350^{\circ} \mathrm{C}$ particularly damaged blue grama (Hart 1992).

\section{Management Implications}

There are many potential drawbacks to conducting prescribed burns for broom snakeweed control on blue grama rangelands. Indeed, Wright and Bailey (1980) argued the use of fire does not produce major beneficial effects in this ecosystem, except in special situations where it is desirable to control shrubs, improve livestock distribution, or remove litter that has stagnated plant growth.

When burning shortgrass prairie under prescribed conditions, Wright and Bailey (1982) recommended head fires be started when relative humidity is $20-40 \%$, air temperature is $21-27^{\circ} \mathrm{C}$, and wind is $4-7 \mathrm{~m} / \mathrm{s}$. Over our 6-year study period (1990-1995), 

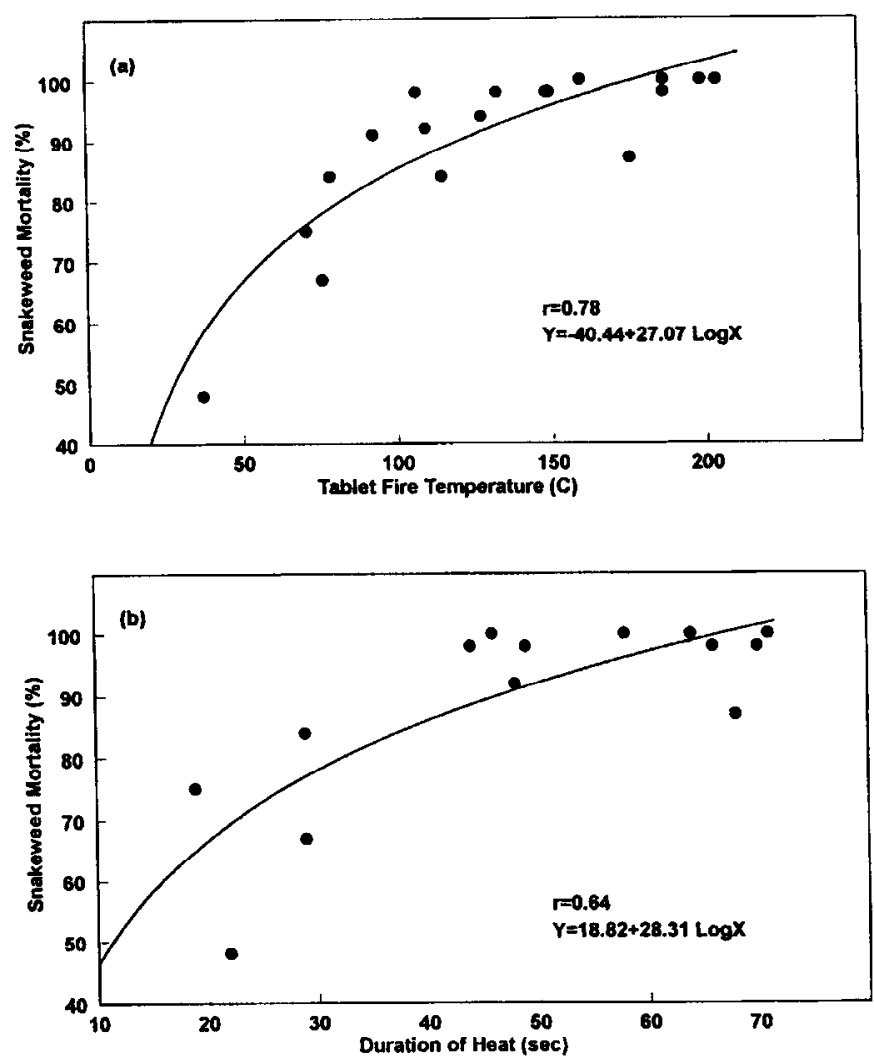

Fig. 1.Relationship between average maximum temperature at ground level (a) and duration of heat (b), to percent broom snakeweed mortality during summer burning on the New Mexico State University Corona Research Ranch.

we rarely experienced the ideal weather conditions provided for by this prescription. On our study area, spring air temperatures are rarely above $20^{\circ} \mathrm{C}$ and winds from the southwest often exceed $10 \mathrm{~m} / \mathrm{s}$. In summer, air temperatures and relative humidity usually do not coincide within the prescribed range except at night. We did not attempt night burning, but for purposes of burning within the Wright and Bailey prescription, this possibility should be investigated. Burning was further complicated by the availability and continuity of fine fuel, and this material was often too moist to burn satisfactorily. Thus, an effective controlled fire must often be generated outside the Wright and Bailey prescription by compensating either with high wind speeds, reduced relative humidity, or elevated air temperatures. While fire containment and safety are major concerns when burning outside the prescription, there are biological problems as well. For example, burning under high wind speeds can move the headfire too rapidly through the shrub's crown, especially in spring, to damage primordial buds on lower stems, thus a relatively high percentage of broom snakeweed plants will survive. As air temperatures elevate in summer, fire temperatures and duration of heat increase and result in a high percentage of broom snakeweed killed. However, if fires generate too much heat, then direct damage to grasses can be severe, especially if above normal precipitation does not occur after the fire (Hopkins et al. 1948, Launchbaugh 1972, Dwyer and Pieper 1967). Reducing post-burn plant cover exposes a higher percentage of bare soil, which enhances the probability of later broom snakeweed germination and establishment (Carroll 1994, Wood et al. 1996).
With the above considerations in mind, we recommend the prescription for burning blue grama grasslands for broom snakeweed control be modified so that air temperatures are from 22 to $28^{\circ} \mathrm{C}$; relative humidity, $10-20 \%$; soil moisture $3-10 \%$; wind from the southwest, $3-8 \mathrm{~m} / \mathrm{sec}$; and fine-fuel moisture below $15 \%$. When blue grama grasslands are burned to control broom snakeweed, success is ultimately governed by heat generated during the burning event, which is a product of weather and fuel conditions under which the fire is conducted (Wright and Bailey 1980). Fuel attributes that influence the rate of spread of a fire and heat produced depend primarily on the quantity and uniformity of the fuel source, as well as the degree of fuel desiccation (Scifres 1980). Inherent limitations in both the quantity and consistency of the fine-fuel source presents a problem with burning blue grama grassland at any time of the year. In central New Mexico, prevailing southwest winds in spring have relatively warmer air temperatures than from other directions, and as indicated by a positive relationship to maximum average thermocouple temperatures $(r=$ $0.60)$ and degree-seconds of heat $(r=0.41)$, are likely to produce hotter fires than with winds from another direction. While there are weather difficulties in producing spring fires with sufficient heat to burn and completely eliminate broom snakeweed, such limitations do not occur with summer burning. The major limitation we encountered when burning in summer was actively growing blue grama that would not ignite. When this fuel was desiccated (moisture below 15\%) it was easily burned.

Because of the problems enumerated above, we believe prescribed fire as an intervention tool for managing broom snakeweed on blue grama grasslands presents a risk that may be unacceptable to many. For example, a successful burn will probably require grazing deferment the growing season before and at least one season after the burning event (Wright and Bailey 1982). There is little certainty that weather will cooperate to produce the needed pre-burn fuel conditions. Just as important, weather may not meet prescribed conditions during the desired burning period. An uncontrollable factor of paramount importance is having sufficient precipitation after the burning event to promote herbaceous growth. Thus, only when ideal weather events converge is fire likely to provide the desired outcome of controlling broom snakeweed and increasing wanted forage.

\section{Literature Cited}

Alexander, M.E. 1982. Calculating and interpreting forest fire intensities. Can. J. Bot. 60:349-357.

Bonham, C.D. 1989. Measurements for terrestrial vegetation. John Wiley and Sons, New York.

Britton, C.M. and H.A. Wright. 1971. Correlation of weather variables to mesquite damage by fire. J. Range Manage. 24:136-141.

Bryam, G.M. 1959. Combustion of forest fuels, p. 61-89. In: K.P. Davis (ed.) Forest fire: Control and use. McGraw-Hill Book Co., New York.

Carroll, D.B. 1994. Broom snakeweed seedling response to spring and summer burning in central New Mexico. M.S. thesis, New Mexico State Univ., Las Cruces, N.M.

Clark, R.G. 1983. Threshold requirements for fire spread in grassland fuels. Ph.D. Diss. Texas Tech Univ., Lubbock, Tex.

DePuit, E.J. and M.M. Caldwell. 1975. Gas exchange of three cool season semi-desert species in relation to temperature and water stress. J. Ecol. 63:835-858. 
Dwyer, D.D. 1969. Broom snakeweed: range problem. Amer. Hereford J. 60:42.

Dwyer, D.D. and R.D. Pieper. 1967. Fire effects of blue grama-pinyonjuniper rangeland in New Mexico. J. Range Manage. 20:359-362.

Engle, D.M., T.G. Bidwell, A.L. Ewing, and J.R. Williams. 1989. A technique for quantifying fire behavior in grassland fire ecology studies. Southwestern Nat., 34:79-84.

Hare, R.C. 1961. Heat effects on living plants. U.S. Forest. Ser. Southern Forest. Exp. Sta. Occas. Pap. 183. 32 pp.

Hart, C.R. 1992. Broom snakeweed and associated herbage response to seasonal burning in New Mexico. Ph.D. Diss., New Mexico State Univ., Las Cruces, N.M.

Heirman, A.L. and H.A. Wright. 1973. Fire in medium fuels in West Texas. J. Range Manage. 26:331-335.

Heyward, F. 1938. Soil temperatures during forest fires in the longleaf pine region. J. Forest. 36:478-491.

Hopkins, H., F.W. Albertson, and A. Riegel. 1948. Some effects of burning upon a prairie in west-central Kansas. Kans. Acad. Sci. Trans. $51: 131-141$.

Jacoby, P.W., R.J. Ansley, and B.A. Trevino. 1992. An improved method for measuring temperatures during range fires. J. Range Manage. 45:216-220.

Launchbaugh, J.L. 1972. Effect of fire on shortgrass and mixed prairie species. Proc. Tall Timbers Fire Ecol. Conf. 12:129-151.

McDaniel, K.C. 1989. Use of herbicides in snakeweed management, p. 85-100. In: E.W. Huddleston and R.D. Pieper (ed.). Snakeweed: Problems and perspectives. New Mexico State Univ. Agr. Exp. Sta. Bull. 751. Las Cruces, N.M.

McDaniel, K.C. and R.W. Duncan. 1987. Broom snakeweed (Gutierrezia sarothrae) control with picloram and metsulfuron. Weed Sci. 35:837-841.

McDaniel, K.C., L.A. Torell, and J.W. Bain. 1993. Overstory-understory relationships for broom snakeweed-blue grama grasslands. J. Range Manage. 46:506-511.
Pieper, R.D. and K.C. McDaniel. 1989. Ecology and management of broom snakeweed, p. 1-12. In: E.W. Huddleston and R.D. Pieper (ed.). Snakeweed: Problems and perspectives. New Mexico State Univ. Agr. Exp. Sta. Bull. 751. Las Cruces, N.M.

Rasmussen, G.A. and H.A. Wright. 1988. Prescribed burning guidelines for perennial broomweed. Broom Snakeweed Conf. Proc., Ft. Sumner, New Mexico, p. 24.

Roberts, F.H., C.M. Britton, D.B. Wester, and R.G. Clark. 1988. Fire effects on tobosa grass and weeping lovegrass. J. Range Manage. 41:407-409.

Rothermel, R.C. and J.E. Deeming. 1980. Measuring and interpreting fire behavior for correlation with fire effects. U.S. Forest. Ser. Gen. Tech. Rep. INT-93.

SAS Institute Inc. 1984. SAS/ETS User's Guide, Version 5 edition. SAS Institute, Inc. Cary, N.C.

Scifres, C.G. 1980. Brush management. Texas A\&M Univ. Press.

Smith, G.S. and G.I. Flores-Rodriguez. 1989. Toxicity of snakeweeds, p. 211-220. In: E.W. Huddleston and R.D. Pieper (ed.). Snakeweed: Problems and perspectives. New Mexico State Univ. Agr. Exp. Sta. Bull. 751. Las Cruces, N.M.

Stinson, K.J. and H.A. Wright. 1969. Temperatures of headfires in the southern mixed prairie of Texas. J. Range Manage. 22:169-174.

Torell, L.A., K. Williams, and K.C. McDaniel. 1989. Economics of broom snakeweed control, p. 113-140. In: E.W. Huddleston and R.D. Pieper (ed.), Snakeweed: Problems and perspectives. New Mexico State Univ. Agr. Exp. Sta. Bull. 751. Las Cruces, N.M.

Wood, B.L., K.C. McDaniel, and D. Clason. 1996. Broom snakeweed (Gutierrezia sarothrae) dispersal, viability, and germination. Weed Sci. (In Press).

Wright, H.A. and A.W. Bailey. 1980. Fire ecology and prescribed burning in the Great Plains - a research review. USDA Gen. Tech. Rep. INT-77. Ogden, Ut.

Wright, H.A. and A.W. Bailey. 1982. Fire Ecology, United States and Southern Canada. John Wiley \& Sons, New York. 